\title{
Erratum to: Generation of MCF-7 cells with aggressive metastatic potential in vitro and in vivo
}

Elke Ziegler $^{1} \cdot$ Marie-Therese Hansen ${ }^{1}$.

Maike Haase $^{1} \cdot$ Günter Emons $^{1} \cdot$ Carsten Gründker $^{1}$

Published online: 1 March 2016

(C) Springer Science+Business Media New York 2016

Erratum to: Breast Cancer Res Treat (2014)

148:269-277

DOI 10.1007/s10549-014-3159-4

In the original publication of the article, the Fig. $2 b$ showing protein expression of Twist was published erroneously. The corrected Fig. $2 \mathrm{~b}$ is given below. The authors apologize for this error.

The online version of the original article can be found under doi:10.1007/s10549-014-3159-4.

$\triangle$ Carsten Gründker

grundker@med.uni-goettingen.de

1 Department of Gynecology and Obstetrics, Georg-August-

University, Robert-Koch-Street 40, 37075 Göttingen,

Germany 
A
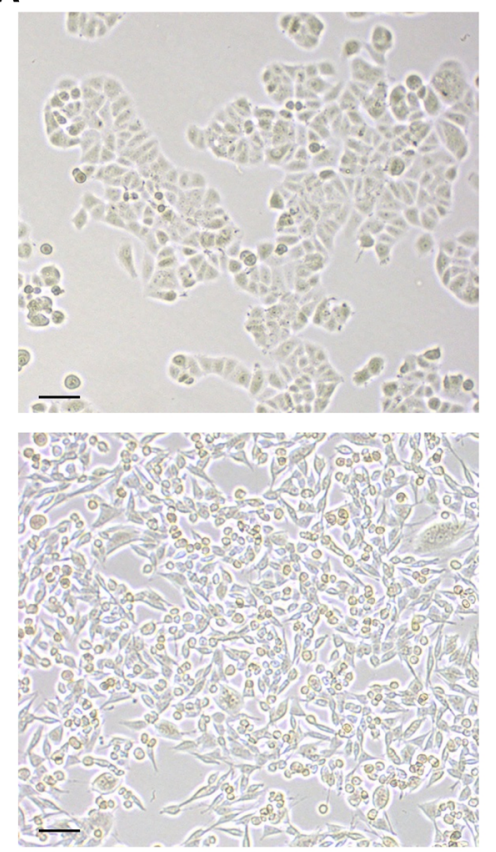

B

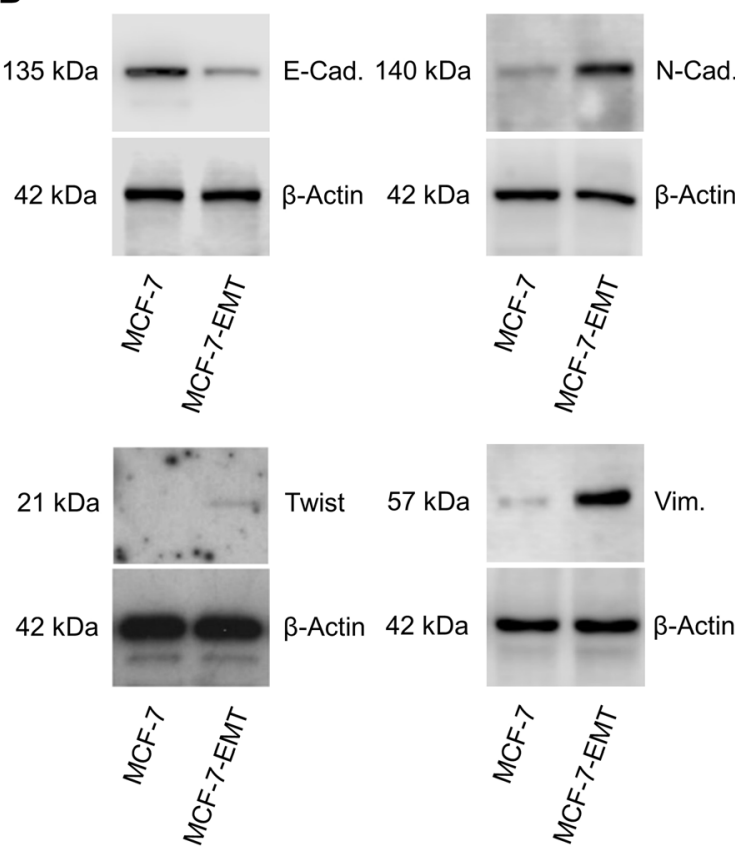

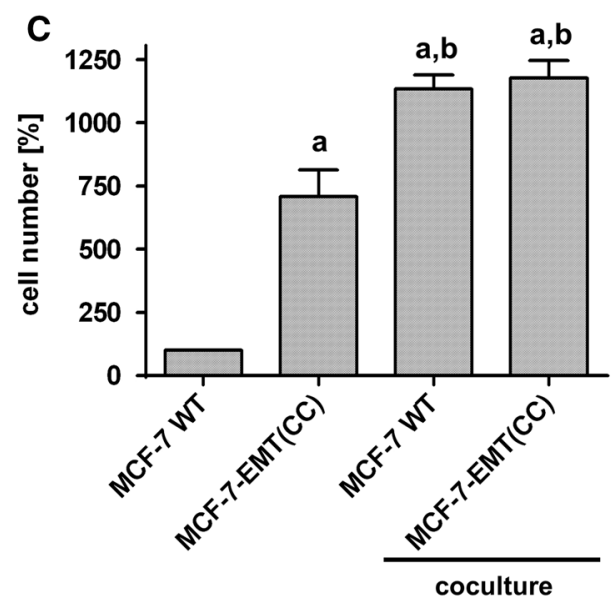

Fig. 2 Morphology of breast cancer cells (a). Breast cancer cell lines MCF-7 WT (above) and MCF-7-EMT(CC) (below) were grown in culture flasks. Bright-field images of living cells were taken (scale bar $100 \mu \mathrm{m})$. Images represent the findings in at least three different passages of each cell line. Experiments using MCF-7-EMT(MC) cells gave identical results with that of MCF-7-EMT(CC) cells. Protein expression of EMT markers (b). Protein expression of epithelial marker CDH1 and mesenchymal markers CDH2, VIM, and TWIST in MCF-7 WT and MCF-7-EMT(CC) cells. Experiments using MCF-7EMT(MC) cells gave identical results with that of MCF-7-EMT(CC) cells. Invasive characteristics of MCF-7 WT and MCF-7-EMT(CC) cells (c). Invasion of the breast cancer cell lines MCF-7 WT and MCF-7-EMT(CC) was studied by a modified Boyden chamber assay for cells in monoculture and cells cocultivated with MG63 osteosarcoma cells (coculture). Numbers of invaded cells were counted after $72 \mathrm{~h}$. Results were analyzed by one-way analysis of variance followed by Student-Newman-Keuls' test for comparison of individual groups, after a Bartlett test had shown that variances were homogenous (mean \pm SEM; a, $p<0.001$ vs. MCF-7 WT monoculture; $\mathrm{b}, p<0.001$ vs. MCF-7-EMT(CC) monoculture). Experiments using MCF-7-EMT(MC) cells gave identical results with that of MCF-7-EMT(CC) cells 